University of Nebraska - Lincoln

DigitalCommons@University of Nebraska - Lincoln

2003

\title{
Optimal Plant Population and Nitrogen Fertility for Dryland Corn in Western Nebraska
}

Jurg M. Blumenthal

Panhandle Res. and Ext. Center

Drew J. Lyon

University of Nebraska-Lincoln, drew.lyon@wsu.edu

Walter Stroup

University of Nebraska-Lincoln, wstroup1@unl.edu

Follow this and additional works at: https://digitalcommons.unl.edu/panhandleresext

Part of the Agriculture Commons

Blumenthal, Jurg M.; Lyon, Drew J.; and Stroup, Walter, "Optimal Plant Population and Nitrogen Fertility for Dryland Corn in Western Nebraska" (2003). Panhandle Research and Extension Center. 2.

https://digitalcommons.unl.edu/panhandleresext/2

This Article is brought to you for free and open access by the Agricultural Research Division of IANR at DigitalCommons@University of Nebraska - Lincoln. It has been accepted for inclusion in Panhandle Research and Extension Center by an authorized administrator of DigitalCommons@University of Nebraska - Lincoln. 


\title{
Optimal Plant Population and Nitrogen Fertility for Dryland Corn in Western Nebraska
}

\author{
Jürg M. Blumenthal, Drew J. Lyon,* and Walter W. Stroup
}

\begin{abstract}
Dryland corn (Zea mays L.) production increased more than 10fold from 1995 through 2000 in semiarid western Nebraska. Corn population and $\mathrm{N}$ fertilizer management recommendations are needed for this area. The objectives of this study were to determine the influence of plant population and $\mathbf{N}$ fertility on corn yields in semiarid western Nebraska. In 1999 and 2000, experiments were conducted each year at four sites. Factorial experimental treatments were five plant populations $(17300,27200,37100,46900$, and 56800 plants $\left.\mathrm{ha}^{-1}\right)$ and five $\mathrm{N}$ fertilizer rates $\left(0,34,67,101\right.$, and $\left.134 \mathrm{~kg} \mathrm{~N} \mathrm{ha}^{-1}\right)$ arranged in a randomized complete block with five blocks. Corn yields ranged from less than $100 \mathrm{~kg} \mathrm{ha}^{-1}$ to more than $5550 \mathrm{~kg} \mathrm{ha}^{-1}$. Overall, grain yield increased $353 \mathrm{~kg} \mathrm{ha}^{-1}$ with increasing population from 17300 to 27200 plants ha $^{-1}$. Population increases above 27200 plants $\mathrm{ha}^{-1}$ resulted in inconsistent yield results. Nitrogen fertilization and plant population effects did not interact. Yields were maximized by $202 \mathrm{~kg} \mathrm{~N} \mathrm{ha}^{-1}$ in the form of soil $\mathrm{NO}_{3}-\mathrm{N}$ and fertilizer $\mathrm{N}$ available before crop emergence. Growers are advised to use a plant population of 27200 plants $\mathrm{ha}^{-1}$. Economic optimal fertilizer rate can be estimated using the equation: $N_{\text {fert. }}=\left(10.6 \times P_{\text {corn }}-P_{\text {fert. }}\right) /(0.0526 \times$ $\left.\boldsymbol{P}_{\text {corn }}\right)-\boldsymbol{N}_{\text {soil }}$, where $\boldsymbol{P}_{\text {corn }}$ and $\boldsymbol{P}_{\text {fert. }}$ are corn and fertilizer price (\$ $\left.\mathrm{kg}^{-1}\right)$, respectively, $N_{\text {soil }}$ is soil test $\mathrm{NO}_{3}-\mathrm{N}\left(\mathrm{kg} \mathrm{ha}^{-1}\right)$ as determined by preplant soil test in a 0 - to $120-\mathrm{cm}$ soil sample, and $\boldsymbol{N}_{\text {fert. }}$ is economic optimal fertilizer rate $\left(\mathrm{kg} \mathrm{ha}^{-1}\right)$.
\end{abstract}

$\mathrm{W}$ ATER IS THE most limiting resource for dryland crop growth in the semiarid areas of the U.S. Great Plains (Smika, 1970). Summer fallow, the practice of controlling all plant growth during the noncrop summer season, was quickly adopted to stabilize winter wheat (Triticum aestivum L.) production in the region (Haas et al., 1974). Wheat-fallow is the predominate cropping system in the Great Plains, but water storage efficiency during fallow is frequently less than $25 \%$ with conventional tillage (McGee et al., 1997). The advent of reduced- and no-till systems has greatly enhanced the ability to capture and retain precipitation in the soil during noncrop periods. Increased storage makes it possible to reduce the frequency of fallow and intensify cropping systems relative to wheat-fallow (Peterson et al., 1996).

Nearly $75 \%$ of annual precipitation in the Great Plains occurs from April to September; therefore, inclusion of a summer crop, e.g., corn or grain sorghum [Sorghum bicolor (L.) Moench] in a 3-yr system of wheatsummer crop-fallow increases the efficient use of precipitation by reducing the frequency of summer fallow and using more water for crop transpiration (Farahani et al., 1998). In addition to increased precipita-

J.M. Blumenthal and D.J. Lyon, Panhandle Res. and Ext. Cent., 4502 Ave. I, Scottsbluff, NE 69361; and W.W. Stroup, Dep. of Biometry, 103 Miller Hall, Univ. of Nebraska, Lincoln, NE 68583-0712. Journal Ser. no. 13384 of the Univ. of Nebraska Agric. Res. Div. Received 11 July 2002. *Corresponding author (DLYON1@unl.edu).

Published in Agron. J. 95:878-883 (2003). tion use efficiency and grain yield, more intensified dryland cropping systems increase potentially active surface soil organic C and N (Wood et al., 1990; Pikul and Aase, 1995; Peterson et al., 1998), effectively control winter annual grass weeds in winter wheat (Daugovish et al., 1999), and increase net return and reduce financial risk (Dhuyvetter et al., 1996).

Growers in the Panhandle of Nebraska have limited experience with dryland corn. Before 1997, fewer than 3800 ha of dryland corn were planted each year. As more growers diversified and intensified their rotations, land planted to corn grew to more than 38800 ha in 2000 (NASS, 2001).

Determining corn plant population response is a recurrent area of study. In one southwest Kansas study, dryland corn performed best when no-till-planted in early to mid-May at plant populations not exceeding 44500 plants ha ${ }^{-1}$ (Norwood and Currie, 1996). A more recent study from this same region achieved maximum yield and water use efficiency with a late May planting, combined with later-maturing hybrids and plant populations up to 60000 plants ha $^{-1}$ (Norwood, 2001). However, in northwest Kansas, no yield differences were found for corn populations of 21000,24700 , and 37100 plants $\mathrm{ha}^{-1}$ (Havlin and Lamm, 1988). In a summary of research results from locations across the USA and Canada, corn grain yields leveled off but did not decrease above the optimum plant population, except in those fields with yield levels below $7500 \mathrm{~kg} \mathrm{ha}^{-1}$ (Paszkiewicz and Butzen, 2001). Modern hybrids typically have a greater tolerance of high plant density than older hybrids (Tollenaar, 1991).

Nitrogen fertilizer recommendations for corn in Nebraska are based predominately on work conducted with irrigation in the central and eastern areas of the state where corn is extensively grown. As dryland corn production moves westward, the validity of the current algorithm for determining $\mathrm{N}$ rate recommendations in corn is questioned. In eastern Colorado, dryland corn grown in a no-till winter wheat-corn-fallow rotation averaged $4520 \mathrm{~kg} \mathrm{ha}^{-1}$ grain and required $1.1 \mathrm{~kg} \mathrm{~N} \mathrm{ha}^{-1}$ uptake to produce $63 \mathrm{~kg} \mathrm{ha}^{-1}$ grain (Kolberg et al., 1996). Halvorson and Reule (1994) found that in eastern Colorado, between 67 and $90 \mathrm{~kg} \mathrm{~N} \mathrm{ha}^{-1}$ should be applied to corn grown in a no-till spring barley (Hordeum vulgare $\mathrm{L}$.)-corn rotation.

The objectives of this study were to determine proper plant population and $\mathrm{N}$ recommendations for dryland corn grown in western Nebraska.

\section{MATERIALS AND METHODS}

Field studies were conducted in 1999 and 2000 at four Nebraska Panhandle locations in each year (Table 1). The experimental design was a randomized complete block with five replicate blocks per site. Factorial treatments were five corn 
Table 1. Site description for each of the eight Nebraska Panhandle corn experiments.

\begin{tabular}{|c|c|c|c|c|}
\hline Site & Year & Soil classification & Lat., long. & Elevation \\
\hline & & & & $\mathbf{m}$ \\
\hline Banner County & 1999 & Tripp very fine sandy loam (Aridic Haplustoll) & $41^{\circ} 34^{\prime} 59^{\prime \prime} \mathrm{N},-103^{\circ} 27^{\prime} 7^{\prime \prime} \mathrm{W}$ & 1260 \\
\hline Box Butte County & 1999 & Creighton very fine sandy loam (Aridic Haplustoll) & $42^{\circ} 9^{\prime} 25^{\prime \prime} \mathrm{N},-103^{\circ} 12^{\prime} 29^{\prime \prime} \mathrm{W}$ & 1310 \\
\hline Cheyenne County & 1999 & Duroc loam (Pachic Haplustoll) & $41^{\circ} 13^{\prime} 52^{\prime \prime} \mathrm{N},-103^{\circ} 1^{\prime} 12^{\prime \prime} \mathrm{W}$ & 1310 \\
\hline Kimball County & 1999 & Rosebud loam (Calcidic Argiustoll) & $41^{\circ} 7^{\prime} 55^{\prime \prime} N,-103^{\circ} 44^{\prime} 31^{\prime \prime} W$ & 1520 \\
\hline Banner County & 2000 & Tripp very fine sandy loam (Aridic Haplustoll) & $\mathbf{4 1}^{\circ} 35^{\prime} \mathbf{6}^{\prime \prime} \mathbf{N},-\mathbf{1 0 3}^{\circ} 27^{\prime} \mathbf{1 4}^{\prime \prime} \mathrm{W}$ & 1260 \\
\hline Box Butte County & 2000 & Alliance loam (Aridic Argiustoll) & $42^{\circ} 8^{\prime} 49^{\prime \prime} \mathbf{N},-103^{\circ} 11^{\prime} 2^{\prime \prime} W$ & 1310 \\
\hline Cheyenne County & 2000 & Keith silt loam (Aridic Argiustoll) & $41^{\circ} 14^{\prime} 6^{\prime \prime} N,-103^{\circ} 1^{\prime} 1^{\prime \prime} W$ & 1310 \\
\hline Kimball County & 2000 & Tripp loam (Aridic Haplustoll) & $41^{\circ} 18^{\prime} 25^{\prime \prime} N,-103^{\circ} 54^{\prime} 4^{\prime \prime} W$ & 1520 \\
\hline
\end{tabular}

plant populations and five $\mathrm{N}$ fertilizer rates. Corn, 'Pioneer 3893', was no-till-seeded in 76-cm rows into winter wheat or proso millet (Panicum miliaceum L.) stubble at a rate of 103000 seed $\mathrm{ha}^{-1}$, and about 3 wk after emergence, plants were thinned to densities of 17300,27 200, 37 100, 46 900, and 56800 plants $\mathrm{ha}^{-1}$. Ammonium nitrate was applied surface broadcast after corn planting, but before emergence, at rates of $0,34,67,101$, and $134 \mathrm{~kg} \mathrm{~N}^{-1}$. Plot size was 3 by $9.1 \mathrm{~m}$.

Gravimetric soil water content was determined by collecting and bulking 10 soil cores per site taken just before planting in $0.3-\mathrm{m}$ increments to a depth of $1.2 \mathrm{~m}$ (Table 2). Before planting, soil samples were taken in depth increments of 0 to $20 \mathrm{~cm}$ for determination of organic matter, $\mathrm{pH}$, Bray-P1 P, and residual soil $\mathrm{NO}_{3}-\mathrm{N}$ content and 20 to $61 \mathrm{~cm}$ and 61 to $122 \mathrm{~cm}$ for determination of residual soil $\mathrm{NO}_{3}-\mathrm{N}$ content according to recommended soil test procedures for corn in Nebraska (Shapiro et al., 2001). Soil analyses were performed at the University of Nebraska Soil and Plant Analysis Laboratory, Lincoln, NE, according to the recommended chemical soil test procedures for the North-Central region of the USA (Anonymous, 1998) (Table 3).

Six of the eight sites were located on producer fields and were managed by the producers. Weed control decisions were discussed with the producers, but they used their best judgment when making weed control decisions. In a couple of instances, hand weeding was performed to eliminate small weed patches.

Grain was harvested mechanically from the middle two rows of each four-row plot for a total harvest area of $13.6 \mathrm{~m}^{2}$. Grain test weight and moisture were determined along with sample weight. Sample weights were adjusted to a $150 \mathrm{~g} \mathrm{~kg}^{-1}$ moisture content basis.

Seasonal rainfall was recorded at the Cheyenne County site in both years. On-site rainfall was collected at the other three sites in 2000. In 1999, rainfall data from the nearest automated weather station were used. These weather stations were as much as $30 \mathrm{~km}$ from a given site, and the data, particularly precipitation data, should be used with caution.

The data were analyzed two ways: first by standard analysis of variance for multienvironment trials, as described in the

Table 2. Gravimetric soil water content in the surface $1.2 \mathrm{~m}$ of soil at planting for each of the eight Nebraska Panhandle corn experiments.

\begin{tabular}{llr}
\hline & \multicolumn{2}{c}{ Gravimetric soil water content } \\
\cline { 2 - 3 } Site & 1999 & 2000 \\
\cline { 2 - 3 } Banner County & & \\
Box Butte County & $0.141 \dagger$ & $\mathbf{0 . 0 8 6}$ \\
Cheyenne County & $\mathbf{0 . 1 7 5} \uparrow$ & $\mathbf{0 . 1 5 3}$ \\
Kimball County & $\mathbf{0 . 1 7 4} \uparrow$ & $\mathbf{0 . 1 7 7}$ \\
\hline
\end{tabular}

$\dagger$ Gravimetric soil water content determined for the surface $0.9 \mathrm{~m}$ of soil at planting because of dry soil conditions that prevented deeper core collection.

$¥$ Gravimetric soil water content determined for the surface $\mathbf{0 . 3} \mathbf{~ m}$ of soil at planting because of a shallow soil profile. next paragraph, and subsequently by more in-depth analysis using environmental indices to quantify dependence of population effects on quality of environment. Data from the 2000 Banner County site were not used in the analysis because the error variance was more than 10 -fold smaller than for any other site-year combination. Sources of variation were environment, block within environment, population and fertilizer main effects, population $\times$ fertilizer interaction, experimental (between environment) error, and sampling (within environment) error. Because environments represented a target population of inference, they were considered random effects. The analysis was computed using SAS PROC MIXED (SAS Inst., 1999) using the model and procedures described by Littell et al. (1996, p. 78 and 83-85). Population effects were decomposed into contrasts to compare population densities of 17300 vs. 27200 plants ha ${ }^{-1}$, for which previous experience suggested increases in yield should be observed, and among densities $\geq 27200$ plants ha $^{-1}$. The among densities $\geq 27200$ plants ha $^{-1}$ comparisons were further decomposed into linear and nonlinear components to address questions concerning the effect, if any, of increased population density above 27200 plants ha $^{-1}$ on yield. Fertilizer effects were partitioned in linear, quadratic, cubic, etc., polynomial regression effects. Fertilizer rates for maximum yield and for economic optimum yield were calculated as described by Black (1993).

Aspects of the population effects appeared to depend on environment. Because standard analysis of variance lacks the power and sensitivity to adequately quantify this dependence, further analysis was computed using an adaptation of a method suggested by Eberhart and Russell (1966) to characterize the impact of environment on treatment effects. The EberhartRussell procedure defined the mean yield of an environment as the "environmental index" and then characterized yield as a function of separate regression over environmental quality, as measured by the index, for each treatment. Littell et al. (2002) demonstrate how to implement this analysis using SAS PROC MIXED. This procedure was used for this analysis,

Table 3. Soil chemical properties for each of the eight Nebraska Panhandle corn experiments. $\dagger$

\begin{tabular}{|c|c|c|c|c|}
\hline Site & pH & Organic matter & $\mathbf{N O}_{3}-\mathbf{N}$ & Bray P-1 \\
\hline & & $\mathbf{g ~ k g}^{-1}$ & \multicolumn{2}{|c|}{$\longrightarrow \mathbf{m g ~ k g}^{-1}$} \\
\hline \multicolumn{5}{|c|}{1999} \\
\hline Banner County & 6.9 & 12 & 2.37 & 36.3 \\
\hline Box Butte County & 6.8 & 11.1 & 2.26 & 16.9 \\
\hline Cheyenne County & 6.4 & 31.6 & 5.38 & 7.2 \\
\hline Kimball County & 7 & 12.4 & 6.67 & 30.1 \\
\hline \multicolumn{5}{|c|}{$\underline{2000}$} \\
\hline Banner County & 6.1 & 14.9 & 1.08 & 30.1 \\
\hline Box Butte County & 6.6 & 11.7 & 1.91 & 16.2 \\
\hline Cheyenne County & 6.5 & 22.4 & 5.49 & 27.8 \\
\hline Kimball County & 6.3 & 8.5 & 0.73 & 24.6 \\
\hline
\end{tabular}

$\dagger$ Test results for organic matter, pH, and Bray $\mathrm{P}-1$ in the $0-20 \mathrm{~cm}$ depth and $\mathrm{NO}_{3}-\mathrm{N}$ in the $0-120 \mathrm{~cm}$ depth, except for the Kimball County site in 1999 where soil depth only allowed sampling to a maximum depth of $30 \mathrm{~cm}$. 


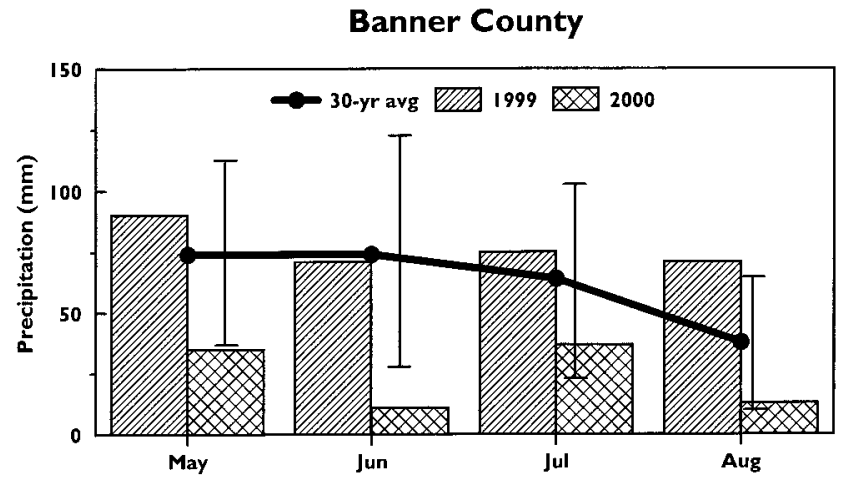

Kimball County

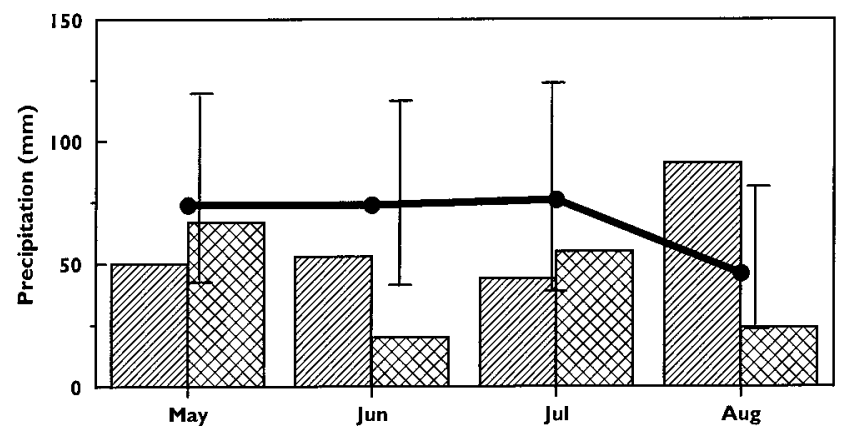

Box Butte County

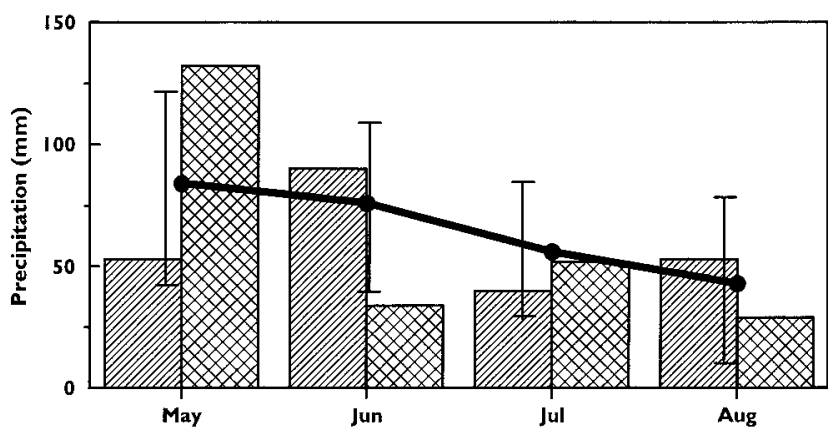

Cheyenne County

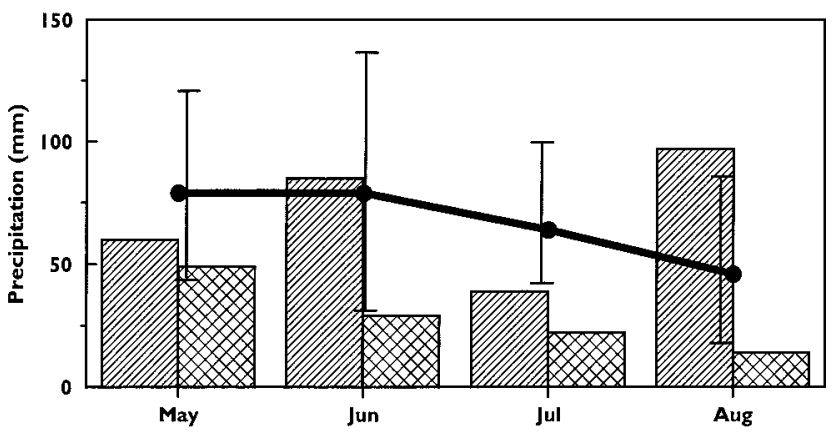

Fig. 1. Monthly (May through August) precipitation at the Banner, Box Butte, Cheyenne, and Kimball County sites in 1999 and 2000. Area within the bars represent + or - one standard deviation from the 30-yr (1961-1990) average monthly precipitation.

with population as the treatment effect and the population effect decomposed into a 17300 vs. 27200 contrast and a linear above 27200 contrast. Thus, for the analysis, the contrast effects change for a given environmental index according to the equation:

Effect at environmental index $=$ main effect +

regression coefficient $\times$ environmental index

\section{RESULTS AND DISCUSSION}

With the exception of the Box Butte County site, summer precipitation was very different between the 2 yr of the study, particularly during the grain fill period of late July and August (Fig. 1). Soil water at planting also varied between the $2 \mathrm{yr}$ and between sites within the same year (Table 2). With above-average August precipitation in 1999, average grain yield for the Banner, Box Butte, Cheyenne, and Kimball County sites were $4860,2920,5550$, and $1640 \mathrm{~kg} \mathrm{ha}^{-1}$, respectively. In 2000 , when August precipitation was below average, grain yield averages were $93,3180,2180$, and $1220 \mathrm{~kg} \mathrm{ha}^{-1}$ for the Banner, Box Butte, Cheyenne, and Kimball County sites, respectively.

A large portion of the potential dryland corn yields for the region was captured within the seven environments used in this analysis. Although this degree of variability results in some difficulties with data interpretation, it accurately represents the situation of the dryland farmer in western Nebraska who has to make plant population and fertilizer decisions in a highly variable climate.

\section{Plant Population}

Linear relationship between plant population and corn yields for each environment are shown in Fig. 2. There was a significant interaction between computed environmental indices and the contrast comparing population densities of 17300 and 27200 plants ha ${ }^{-1}(P \leq$ 0.001). Yield changes from 17300 to 27200 plants ha $^{-1}$ were estimated using the following function:

Yield $=-642+0.32 \times$ environmental index

Kimball County in 2000 was the lowest-yielding environment analyzed in this study, with an environmental index of $1220 \mathrm{~kg} \mathrm{ha}^{-1}$ (Table 4). Equation [1] predicts that, on average, yield decreased $249 \mathrm{~kg} \mathrm{ha}^{-1}$ as population increased from 17300 to 27200 plants ha ${ }^{-1}$. However, at Cheyenne County in 1999 (environmental index = $5550 \mathrm{~kg} \mathrm{ha}^{-1}$ ), Eq. [1] predicts yield increased $1150 \mathrm{~kg}$ $\mathrm{ha}^{-1}$ with increasing population from 17300 to 27200 plants $\mathrm{ha}^{-1}$. The break-even environmental index, i.e., the environmental index at the point where the effect is 0 , was estimated at $1980 \mathrm{~kg} \mathrm{ha}^{-1}$. Yield increases, therefore, are anticipated as population is increased from 17300 to 27200 plants ha $^{-1}$ if site productivity exceeds $1980 \mathrm{~kg} \mathrm{ha}^{-1}$, as it did at five of seven environments in this study (Table 4). Yield decreases are expected over this same population range when site yields are less than $1980 \mathrm{~kg} \mathrm{ha}^{-1}$, e.g., Kimball County in 1999 and 2000. Yield decreases at these two environments were relatively small compared with the magnitude of yield increases estimated at the other environments (Table 4). 


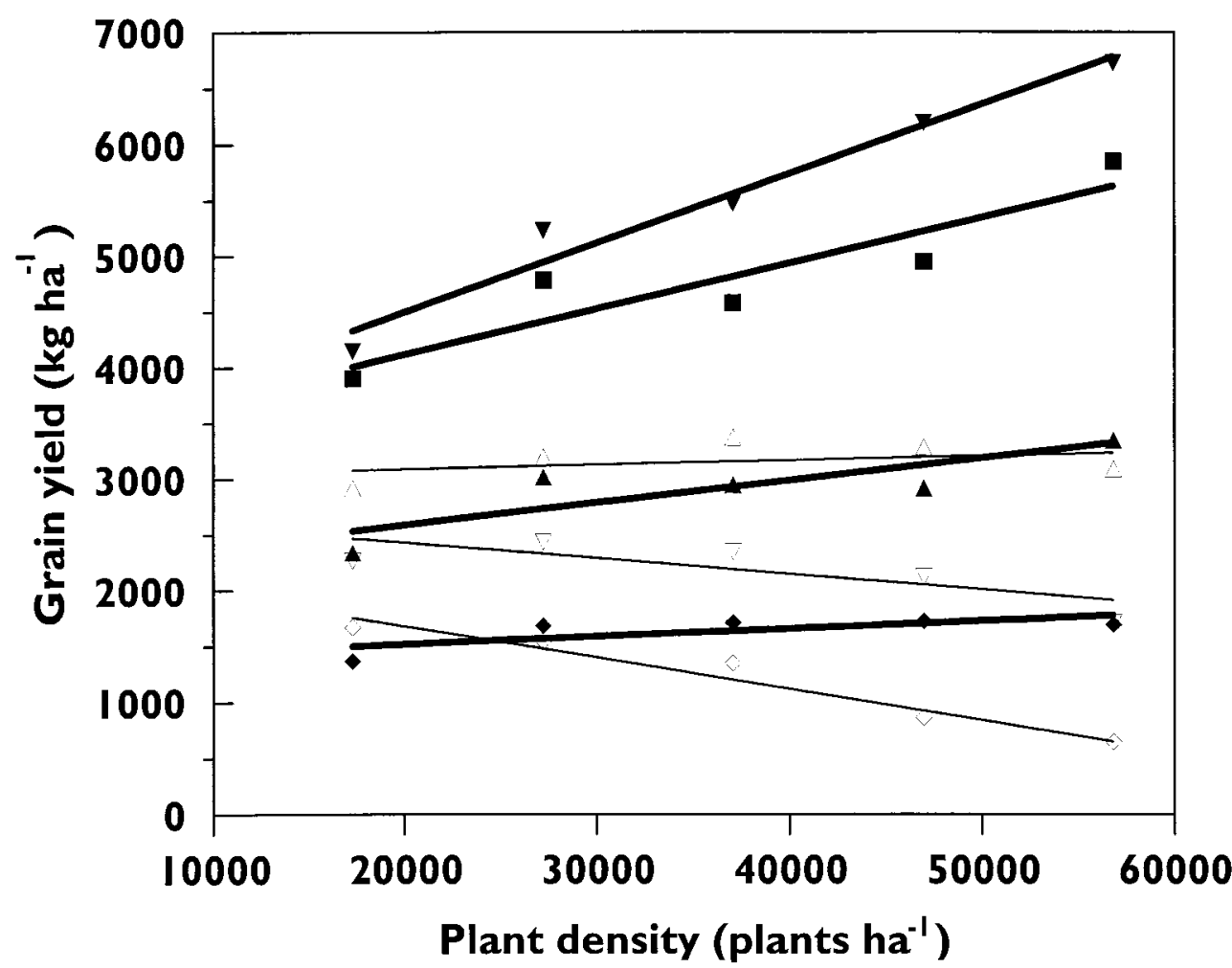

- Banner 1999

- Box Butte 1999

- Box Butte 2000

$\checkmark$ Cheyenne 1999

Cheyenne 2000

- Kimball 1999

Kimball 2000

Fig. 2. Linear relationships between corn yields and plant populations at the Banner County site in 1999 and Box Butte, Cheyenne, and Kimball County sites in 1999 and 2000 . At each environment, yield data were averaged over fertilizer $N$ treatments as there was no interaction between the population and the fertilizer effect $(P>0.05)$.

There was a significant interaction between the environmental indices and the linear component of the contrast comparing among population densities $\geq 27200$ plants ha ${ }^{-1}(P \leq 0.001)$. Slope parameters were estimated using the following function:

$$
\text { Slope }=-0.068+0.0000275 \times \text { environmental index }
$$

Again, using Kimball County 2000 to represent the lowest-yielding environment, the estimate for linear slope above 27200 plants ha ${ }^{-1}$ was $-0.0349 \mathrm{~kg} \mathrm{ha}^{-1}$ for each additional plant per hectare (Table 4). At Cheyenne County in 1999, the slope was estimated at $0.0844 \mathrm{~kg}$ $\mathrm{ha}^{-1}$. Those environments with indices greater than 2480 $\mathrm{kg} \mathrm{ha}^{-1}$ should benefit from population density increases above 27200 plants ha ${ }^{-1}$. Three of the seven environments in this study had environmental indices less than $2480 \mathrm{~kg} \mathrm{ha}^{-1}$, and yield at these sites was reduced as population density increased above 27200 plants ha $^{-1}$ (Table 4). Although significant yield increases occurred in several environments as population was increased above 27200 plants $\mathrm{ha}^{-1}$, in a nearly equal number of cases, significant yield decreases occurred.

Use of environmental indices highlights that the response of grain yield to plant population is affected by the environment's influence on productivity. However, our ability to estimate the productivity of a site at, or before, planting is poor. Soil water at planting does not appear to be a good predictor of yield, e.g., soil water levels at planting at the Cheyenne County site were very similar in 1999 and 2000 (Table 2), but average yields in 2000 were less than $40 \%$ of 1999 yields. Research in northeast Colorado suggests that precipitation during the 6 wk from 15 July through 25 August, or from flowering through early grain fill, can explain as much as $70 \%$ of the yield variation in dryland corn (D. Nielsen,

Table 4. Environmental indices and estimates of the effects of plant population density on yield at seven site-year combinations (environments) in western Nebraska in 1999 and 2000.

\begin{tabular}{|c|c|c|c|c|c|}
\hline \multirow[b]{2}{*}{ Environment } & \multirow[b]{2}{*}{ Environmental index $\dagger$} & \multicolumn{2}{|c|}{ Population increase from 17300 to 27200 plants ha $^{-1}$} & \multicolumn{2}{|c|}{ Population increase above 27200 plants ha $^{-1}$} \\
\hline & & Est. yield change & SE (estimate) & Est. yield change/ additional plant ha ${ }^{-1}$ & SE (estimate) \\
\hline County and year & $\mathbf{k}$ & $\mathrm{ha}^{-1}$ & & $\mathbf{k g ~ h a}^{-1}$ & \\
\hline Banner 1999 & 4860 & 929 & 79.5 & 0.0652 & 0.0051 \\
\hline Box Butte 1999 & 2920 & 301 & 51.1 & 0.0118 & 0.0033 \\
\hline Box Butte 2000 & 3180 & 385 & 51.0 & 0.019 & 0.0032 \\
\hline Cheyenne 1999 & 5550 & 1150 & 98.8 & 0.0844 & 0.0063 \\
\hline Cheyenne 2000 & 2180 & 62 & 59.1 & -0.0084 & 0.0038 \\
\hline Kimball 1999 & 1640 & -112 & 70.2 & $-\mathbf{0 . 0 2 3 2}$ & 0.0045 \\
\hline Kimball 2000 & 1220 & -249 & 80.8 & $-\mathbf{0 . 0 3 4 9}$ & 0.0052 \\
\hline Average & 3080 & 353 & 50.8 & 0.0163 & 0.0032 \\
\hline
\end{tabular}

$\dagger$ Mean yield of an environment. 
personal communication, 2001). Unfortunately, we are unable to accurately predict July and August precipitation at planting time.

Averaged across all environments, yield increased 353 $\mathrm{kg} \mathrm{ha}^{-1}$ with increasing population from 17300 to 27200 plants ha ${ }^{-1}$. In fields that yielded less than $1980 \mathrm{~kg} \mathrm{ha}^{-1}$, yields did not increase with increasing population from 17300 to 27200 plants $\mathrm{ha}^{-1}$. If the productivity at a site was greater than $2480 \mathrm{~kg} \mathrm{ha}^{-1}$, then increasing the population above 27200 plants $\mathrm{ha}^{-1}$ may further increase yield.

In a 2-yr study conducted in the U.S. Corn Belt, there was no yield penalty for planting above the optimum plant population, except at yield levels below $7500 \mathrm{~kg}$ ha $^{-1}$ (Paszkiewicz and Butzen, 2001). This flat yield response as population increased above the optimum allows growers in the Corn Belt to select planting rates on the high side to allow the crop to take full advantage of favorable conditions, knowing that with less favorable weather, the only loss is the extra seed cost (Hoeft et al., 2000). However, given the lower yield potential of dryland corn in western Nebraska than in the U.S. Corn Belt, seed costs have a proportionately larger affect on profitability than in more productive regions. Dryland corn growers in western Nebraska are advised to plant for an expected harvest population of 27200 plants ha $^{-1}$ and only increase above this level if they are willing to accept the greater risks associated with that decision.

\section{Nitrogen Fertility}

Nitrogen fertilization increased corn yields at six of eight sites. There was no interaction between plant pop- ulation and fertilization rates. Two quadratic relationships, one for a plant population of 17300 and one for plant populations $>27200$, described corn yield as a function of $\mathrm{N}$ available before crop emergence (Fig. 3). The two regression equations vary only in their intercept terms. Therefore, available soil $\mathrm{NO}_{3}$ plus fertilizer $\mathrm{N}$ for maximum yield and economic optimal fertilizer rate were independent of plant population. Using the relationship in Fig. 3 and applying standard mathematical procedures as described by Black (1993), we determined that yields were maximized by $202 \mathrm{~kg} \mathrm{~N}^{-1}$ in the form of soil $\mathrm{NO}_{3}-\mathrm{N}$ and fertilizer $\mathrm{N}$ available before crop emergence. Applying standard procedures as described by Black (1993), fertilizer N requirement for economic optimal yields with maximum return to fertilization were determined according to the following equation:

$$
N_{\text {fert. }}=\frac{\left(10.6 \times P_{\text {corn }}-P_{\text {fert }}\right)}{\left(0.0526 \times P_{\text {corn }}\right)}-N_{\text {soil }}
$$

where $P_{\text {corn }}$ and $P_{\text {fert. }}$ are corn and fertilizer price $\left(\$ \mathrm{~kg}^{-1}\right)$, respectively, $N_{\text {soil }}$ is soil test $\mathrm{NO}_{3}-\mathrm{N}\left(\mathrm{kg} \mathrm{ha}^{-1}\right)$ as determined by preplant soil test in a 0 - to $120-\mathrm{cm}$ soil sample, and $N_{\text {fert. }}$ is economic optimal fertilizer rate $\left(\mathrm{kg} \mathrm{ha}^{-1}\right)$. Under the current price scenario $\left(\$ 0.44 \mathrm{~kg}^{-1} \mathrm{~N}\right.$ and $\$ 0.08$ $\mathrm{kg}^{-1}$ corn), $97 \mathrm{~kg} \mathrm{~N} \mathrm{ha}^{-1}$ derived from soil and fertilizer $\mathrm{N}$ would be necessary to produce economic optimal yields. Halvorson and Reule (1994) reported for a study on dryland corn grown in Colorado that a $\mathrm{N}$ supply of about $190 \mathrm{~kg} \mathrm{~N} \mathrm{ha}{ }^{-1}$ was needed to produce $95 \%$ of maximum yield, which they defined as the economic optimal yield level. The discrepancy between these val-

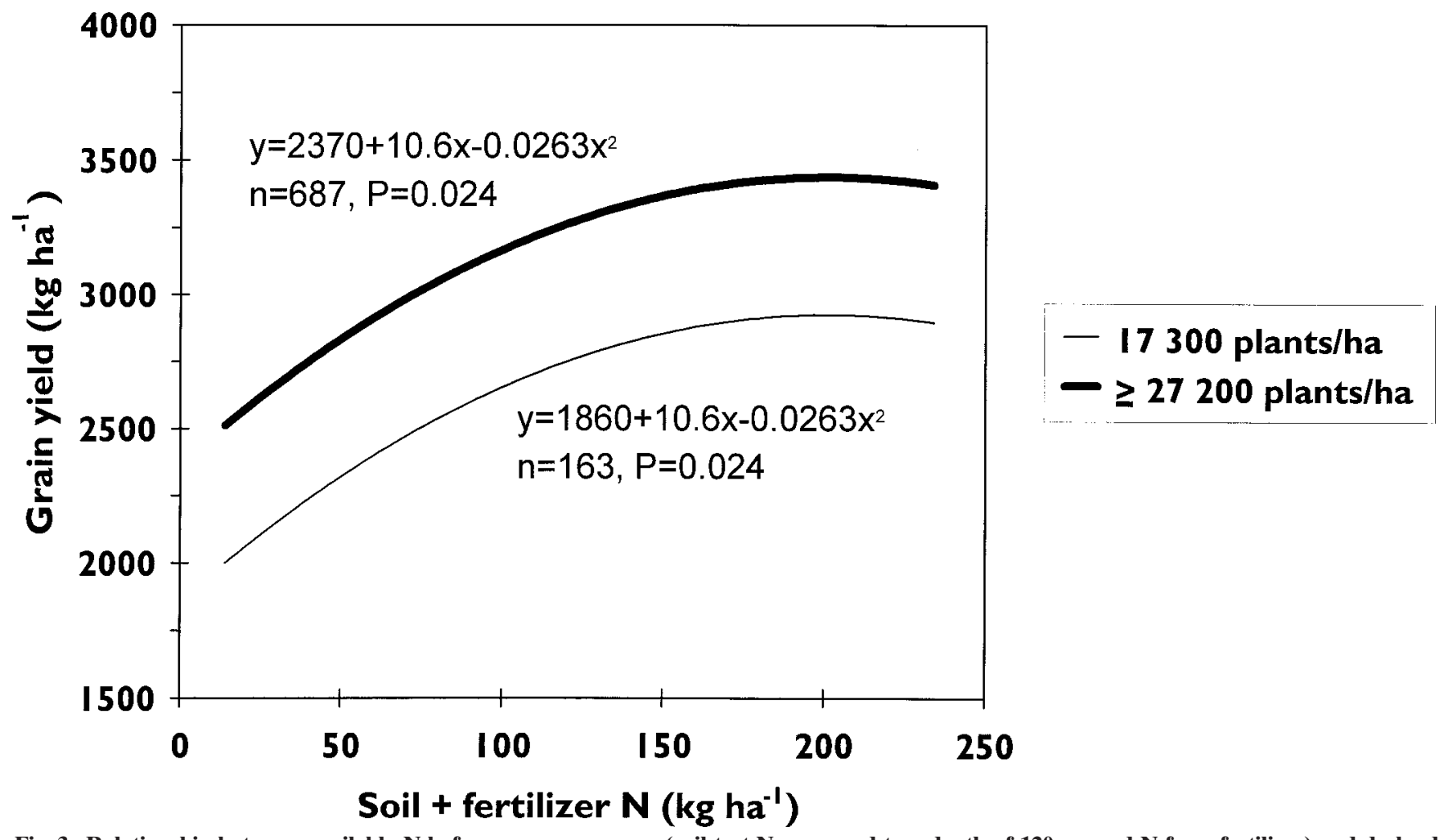

Fig. 3. Relationship between available $\mathbf{N}$ before crop emergence (soil test $\mathbf{N}$ measured to a depth of $120 \mathrm{~cm}$ and $\mathrm{N}$ from fertilizer) and dryland corn yield in western Nebraska in 1999 and 2000. 
ues and the values determined in our study most likely have two reasons: (i) the corn yields we observed were, on average, $40 \%$ lower than theirs, likely the result of our more severe moisture constraints and lower heat unit accumulation associated with increased latitude and (ii) corn and fertilizer price relationships were not considered in their study.

Nitrogen fertilizer recommendations for corn grown in humid environments or under irrigation commonly do not expressively include corn-fertilizer price relationships (Shapiro et al., 2001). The reason for this is that the relationship between corn yield and available $\mathrm{N}$ is very steep and changes in the corn/fertilizer price ratio affect economic optimal fertilization under these conditions very little (C. Shapiro, personal communication, 2001). For dryland corn grown in a semiarid environment, however, the relationship between corn yield and available $\mathrm{N}$ is rather flat (Halvorson and Reule, 1994); therefore, changes in the corn/fertilizer price ratio have a more profound impact on economic optimal fertilization. As an example, corn prices varied between $\$ 0.069$ and $\$ 0.127 \mathrm{~kg}^{-1}$ over the period from $1995-2000$ (NASS, 2001). Assuming a fertilizer price of $\$ 0.44 \mathrm{~kg}^{-1}$ $\mathrm{N}$ and applying the above equation, $80 \mathrm{~kg} \mathrm{~N} \mathrm{ha}^{-1}$ derived from soil and fertilizer $\mathrm{N}$ would be necessary to produce economic optimal yields at the lowest corn price for this period and $135 \mathrm{~kg} \mathrm{~N} \mathrm{ha}^{-1}$ at the high corn price, respectively.

\section{CONCLUSIONS}

Our results document the tremendous variability in dryland corn grain yields in western Nebraska. Over the long run, our results suggest that dryland corn growers in western Nebraska would optimize grain yield and profitability by choosing a plant population of about 27200 plants $\mathrm{ha}^{-1}$. Improved ability to estimate potential grain yield at planting may allow growers to adjust plant populations to take advantage of productive environments and protect against loss in unproductive environments. Economic optimal $\mathrm{N}$ fertilizer rate did not depend on plant population. Estimating economic optimal $\mathrm{N}$ fertilizer rate requires a preplant soil test in addition to fertilizer and corn prices.

\section{ACKNOWLEDGMENTS}

We thank L. Darnall, D. Laursen, and D. Yung for helping us with the experiments on their farms and R. Higgins and R. Nielsen for their capable technical assistance.

\section{REFERENCES}

Anonymous. 1998. Recommended chemical soil test procedures for the north central region. NCR Res. Publ. 221. Missouri Agric. Exp. Stn., Columbia.

Black, C.A. 1993. Soil fertility evaluation and control. Lewis Publ., Boca Raton, FL.
Daugovish, O., D.J. Lyon, and D.D. Baltensperger. 1999. Cropping systems to control winter annual grasses in winter wheat (Triticum aestivum). Weed Technol. 13:120-126.

Dhuyvetter, K.C., C.R. Thompson, C.A. Norwood, and A.D. Halvorson. 1996. Economics of dryland cropping systems in the Great Plains: A review. J. Prod. Agric. 9:216-222.

Eberhart, S.A., and W.A. Russell. 1966. Stability parameters for comparing varieties. Crop Sci. 6:36-40.

Farahani, H.J., G.A. Peterson, D.G. Westfall, L.A. Sherrod, and L.R. Ahuja. 1998. Soil water storage in dryland cropping systems: The significance of cropping intensification. Soil Sci. Soc. Am. J. 62: 984-991.

Haas, H.J., W.O. Willis, and J.J. Bond. 1974. Summer fallow in the western United States. USDA-ARS. Conserv. Res. Rep. 17. U.S. Gov. Print. Office, Washington, DC.

Halvorson, A.D., and C.A. Reule. 1994. Nitrogen fertilizer requirements in an annual dryland cropping system. Agron. J. 86:315-318.

Havlin, J.L., and F.R. Lamm. 1988. Management of dryland corn for the central Great Plains. p. 837-838. In P.W. Unger et al. (ed.) Challenges in dryland agriculture-a global perspective. Proc. Int. Conf. on Dryland Farming, Amarillo, TX. 15-17 Aug. 1988. Texas Agric. Exp. Stn., College Station.

Hoeft, R.G., E.D. Nafziger, R.R. Johnson, and S.R. Aldrich. 2000 Modern corn and soybean production. MCSP Publ., Champaign, IL.

Kolberg, R.L., N.R. Kitchen, D.G. Westfall, and G.A. Peterson. 1996. Cropping intensity and nitrogen management impact dryland notill rotations in the semi-arid western Great Plains. J. Prod. Agric. 9:517-522.

Littell, R.C., G.A. Milliken, W.W. Stroup, and R.D. Wolfinger. 1996. SAS system for mixed models. SAS Inst., Cary, NC.

Littell, R.C., W.W. Stroup, and R.J. Freund. 2002. SAS system for linear models. 4th ed. SAS Inst., Cary, NC.

McGee, E.A., G.A. Peterson, and D.G. Westfall. 1997. Water storage efficiency in no-till dryland cropping systems. J. Soil Water Conserv. 52:131-136.

[NASS] Nebraska Agricultural Statistics Service. 2001. 2000-2001 Nebraska agricultural statistics. NASS, Lincoln, NE.

Norwood, C.A. 2001. Planting date, hybrid maturity, and plant population effects on soil water depletion, water use, and yield of dryland corn. Agron. J. 93:1034-1042.

Norwood, C.A., and R.S. Currie. 1996. Tillage, planting date, and plant population effects on dryland corn. J. Prod. Agric. 9:119-122.

Paszkiewicz, S., and S. Butzen. 2001. Corn hybrid response to plant population. Crop Insights 11(6):1-5. Pioneer Hi-Bred Int., Johnston, IA.

Peterson, G.A., A.D. Halvorson, J.L. Havlin, O.R. Jones, D.J. Lyon, and D.L. Tanaka. 1998. Reduced tillage and increasing cropping intensity in the Great Plains conserves soil C. Soil Tillage Res. 47: 207-218.

Peterson, G.A., A.J. Schlegel, D.L. Tanaka, and D.R. Jones. 1996. Precipitation use efficiency as affected by cropping and tillage systems. J. Prod. Agric. 9:180-186.

Pikul, J.L., Jr., and J.K. Aase. 1995. Infiltration and soil properties as affected by annual cropping in the northern Great Plains. Agron. J. 87:656-662.

SAS Institute. 1999. SAS system for personal computers. Release 8.0. SAS Inst., Cary, NC.

Shapiro, C.A., R.B. Ferguson, G.W. Hergert, A.R. Dobermann, and C.S. Wortmann. 2001. G74-174-A. Fertilizer suggestions for corn. Univ. of Nebraska Coop. Ext., Lincoln.

Smika, D.E. 1970. Summer fallow for dryland winter wheat in the semiarid Great Plains. Agron. J. 62:15-17.

Tollenaar, M. 1991. Physiological basis of genetic improvement of maize hybrids in Ontario from 1959 to 1988. Crop Sci. 31:119-124.

Wood, C.W., D.G. Westfall, G.A. Peterson, and I.C. Burke. 1990. Impacts of cropping intensity on carbon and nitrogen mineralization under no-till dryland agroecosystems. Agron. J. 82:1115-1120. 